\title{
O RESGATE E A SUBVERSÃO DO MITO HISTÓRICO EM O CONQUISTADOR, DE ALMEIDA FARIA
}

Silvani Lopes Lima

\begin{abstract}
RESUMO: Este artigo é resultante de uma dissertação de mestrado, defendida em 2006. No presente texto, buscamos realizar uma análise da obra estudada sob dois aspectos: do resgate e da subversão de um mito histórico da cultura portuguesa, uma vez que o autor retoma a trajetória de Dom Sebastião e o nascimento do mito do sebastianismo para construir o seu protagonista e, ao mesmo tempo, faz a subversão disso quando propõe uma reencarnação do rei às avessas. Entre as conceituações teóricas que fundamentam essa leitura, trabalhamos com a ideia de mito enquanto ideologia, proposta por Roland Barthes, e com algumas formulações sobre ironia e paródia que Mikhail Bakhtin levanta na obra rabelaisiana, as quais julgamos aplicáveis ao contexto de nossa pesquisa. $O$ texto de Faria apresenta um personagem em permanente crise identitária, que carrega o estigma de ser fisicamente idêntico ao famoso rei, mas possui uma personalidade bastante diversa da dele.
\end{abstract}

Palavras-chave: Literatura Portuguesa. Mito do Sebastianismo. História.

\section{INTRODUÇÃO}

Para a constituição deste texto, partimos da ideia de que se evidencia no romance $O$ Conquistador, de Almeida Faria, a busca de identidade do narrador, mesmo que essa busca não se satisfaça ou cesse ao fim da narrativa, por meio do espelhamento, às avessas, entre a vida deste e a de uma das figuras mais polêmicas e inusitadas da história de Portugal, transfigurada em mito, o rei $D$. Sebastião. Ao realizar uma autobiografia precoce, o protagonista organiza as experiências vividas até então, bastante numerosas e intensas para a idade de 24 anos, para compreender-se um pouco mais.

Almeida Faria publicara até então obras que estavam diretamente ligadas a acontecimentos históricos recentes. Rumor Branco (1962), romance inaugural do autor, escrito em contexto de ditadura, revela pela linguagem 
densa e fragmentada, o contexto de sua produção. As demais obras compuseram a chamada "tetralogia lusitana", integrada por A Paixão (1965), Cortes (1978), Lusitânia (1982) e Cavaleiro Andante (1983). Nesses romances, uma mesma família protagoniza as ações e vive os acontecimentos de antes, durante e depois do 25 de abril de 1974, data da revolução civil que pôs fim à ditadura salazarista em Portugal. Trata-se de uma família de latifundiários desestruturada, marcada pela incomunicabilidade entre os membros que vivem juntos, mas não convivem; cada personagem se fecha no seu mundo particular e preocupa-se com seus próprios problemas existenciais.

Todos esses romances de Almeida Faria são construídos em contraposição à narrativa clássica, possuem uma linguagem fragmentada sintática e semanticamente, que mistura quase sempre sonhos e divagações mentais (fluxos de consciência) com o plano da ação narrada. Poderíamos dizer que o texto traduz o desencontro do sujeito com o mundo circundante, aquilo que gera a incomunicabilidade que, na melhor das hipóteses, se resolve através de cartas, mas não em um diálogo direto, portanto a leitura nunca é fácil e linear.

Nesse sentido, seu último romance vem romper com um estilo de escrita do autor. O Conquistador é uma narrativa linear, sem fragmentação da linguagem, constituindo um texto fluente e leve. O narrador, cujo nome é Sebastião de Castro, conta a própria história, mas a memória dos episódios vividos não lhe vem fragmentada, e sim em um relato ordenado, no qual um acontecimento implica em outro. A história segue a cronologia da vida do narrador, desde o nascimento até o momento a partir do qual ele narra, sendo que as sete partes do livro revelam etapas da vida de Sebastião, fases de suas conquistas amorosas. Pela memória, o narrador percorre o período de vinte a quatro anos e, pela escrita, o período de sete meses. Portanto, o passado é narrado a partir do presente.

A narrativa, que principia com o relato sobre o nascimento do narradorprotagonista, mostra fluidez na maneira como expõe esse acontecimento primordial incomum. Conforme lhe contara a avó materna, o pai o encontrou na praia, dentro de um ovo já rompido e sob os cuidados de uma cobra-marinha, de quem precisou resgatá-lo. Esse episódio é marcado por circunstâncias misteriosas (uma tempestade incomum na noite que antecedera os fatos, o encontro com uma "ave rara" em forma de criança em um cenário póstempestade que é quase pós-apocalíptico, a lenda que surge em torno dessa criança, etc.), através das quais o narrador conduz magistralmente a narrativa, enredando o leitor em uma trama bastante intrigante. Ao mesmo tempo, o tom de troça dá leveza ao relato sobre o surgimento do herói, em especial quando são apresentadas as testemunhas do acontecimento: "um cavaleiro maneta, mestre equestre, que para ali ia montar acompanhado pelos seus três peões de brega, recrutados entre os mais aparvalhados das aldeias." (FARIA, 1993, p. 11). Ora, se um cavaleiro maneta, por si só, já não atende aos atributos de um cavaleiro que se preze, a situação se agrava quando este vem 
acompanhado por peões escolhidos "entre os mais aparvalhados" das redondezas. Ou seja, trata-se de um cavaleiro incapacitado e, por isso mesmo risível, acompanhado de três idiotas, o que em tudo desqualifica as testemunhas arroladas pela avó.

Esse tom fluido e bem humorado, embora muitas vezes de um humor irônico e mesmo sarcástico, acompanhará toda a narrativa de O Conquistador, como veremos adiante.

\section{BREVE REVISÃO CRÍTICA}

Ficcionista e ensaísta, Almeida Faria obteve o Prêmio Revelação de Romance da Sociedade Portuguesa de Escritores com o livro Rumor Branco (1962), confirmando depois a sua maturidade literária com A Paixão (1965), primeiro romance de sua "tetralogia lusitana" da qual fazem parte Cortes (1978) - Prêmio Aquilino Ribeiro da Academia das Ciências de Lisboa, Lusitânia (1980) - Prêmio Dom Dinis da Fundação da Casa de Matheus, e Cavaleiro Andante (1983) - Prêmio Originais de Ficção da Associação Portuguesa de Escritores. Em 1990, o autor publicou O Conquistador, objeto de nosso estudo.

O gancho entre ficção e História é percebido e analisado em toda a crítica da obra de Almeida Faria. Na fortuna crítica do autor, destacam-se dois aspectos fundamentais: uma leitura do aspecto irônico da obra; e uma leitura do aspecto da fragmentação da narrativa. A característica irônica da narrativa, por sua vez, facilita a inversão paródica, outra marca de sua ficção.

$\mathrm{Na}$ linha de análise da fragmentação da narrativa, destaca-se a crítica Maria de Lourdes Netto Simões, uma das referências de estudo mais contundentes em língua portuguesa sobre Almeida Faria. Ela elabora uma análise que perpassa todos os romances do autor, levantando alguns momentos históricos importantes para a sua ficção, especialmente a ditadura salazarista e a deposição desse governo com a Revolução dos Cravos. Em sua crítica, a pesquisadora faz um contraponto dos romances do autor com a História e ressalta a fragmentação de seus textos como uma marca do momento de produção das obras, tempos de revolução.

Em sua tese de doutoramento (SIMÕES, 1998), a estudiosa examina o desenvolver dos recursos comunicacionais na narrativa, acreditando que a ficção portuguesa contemporânea evoluiu nos seus processos de construção textual em paralelo e interagindo com o transcorrer revolucionário do 25 de abril de 1974. Procura detectar em que níveis ocorreram mudanças ao longo desse percurso tomando para análise a obra ficcional de Almeida Faria. Em seu estudo, trabalha a obra de Faria em dois níveis de análise: do enunciado, observando o aspecto estrutural; e da enunciação, observando as formas de dizer e as razões do imaginário - aí situado o mito, tendo relevância as formas do mito de D. Sebastião enquanto resgate esclarecedor do presente e enquanto (re)visão do passado. No que se refere ao aspecto histórico, a autora considera que é no contexto de 25 de abril de 1974 que surge a obra de Almeida Faria, e que o olhar do autor sobre essa histórica data se dá pelo lado 
da subjetividade de seus personagens. O escritor toma a História como referente da sua ficção, mas não mantém compromisso com a fidelidade histórica, e a interação entre texto e referente estabelece tensão entre o que o texto diz e o que conhecemos da História.

Conforme a autora, nesse contexto, a linguagem deixa de ser meio e passa a ser elemento - linguagem-fim. A narrativa tenta espelhar o mundo presente já que não pode ficar presa ao passado e, destituída de ilusões, ela já não objetiva solucionar problemas existenciais, mas apenas constatar a situação do homem no mundo. Nesse sentido, a ficção narrativa de Almeida Faria é fragmentada e exigente da participação do leitor na busca de significado para o texto. (SIMÕES, 1975).

No que se refere ao aspecto irônico da produção, Márcia Valéria Gobbi (1997) estuda dois textos de Almeida Faria: O Conquistador e Lusitânia. Para Gobbi, esses dois textos trazem uma leitura crítica da história de Portugal, neste estudo, entretanto, iremos nos deter nas considerações que a autora faz em torno da primeira obra, objeto de nossa análise. Gobbi faz um contraste entre as obras Rumor Branco e O Conquistador, ambos os textos, segundo ela, surpreendentes por diferentes motivos. O primeiro, pela estreia de uma narrativa caótica, fragmentada, de enredo difuso, quase inapreensível; e o último, pelo retorno à narrativa linear, analéptica e unívoca, um romance dentro da linhagem sólida da ficção de prosa. Mas, enquanto o primeiro romance incomodava pela difícil linguagem, esse último incomoda pelo modo irreverente como trata o mito maior do imaginário português, D. Sebastião. O narradorprotagonista nos narra uma vida de exceção, repleta de conquistas, ainda que amorosas; ele não objetiva territórios, mas a figura feminina. Inúmeras coincidências marcam a vida dos dois "heróis" presentes no romance, o fictício (Sebastião de Castro) e o histórico ou mítico (D. Sebastião).

Gobbi (1997) afirma que, nesse sentido, se pode identificar $O$ Conquistador como mítico sob duas perspectivas: uma de que o primeiro mito a ser desconstruído em torno do mito é que ele se opõe à História. Temos aí uma "história verdadeira", conforme a criação ficcional, que busca uma "explicação de si e do mundo"; vemos narrada a criação do narradorprotagonista. Mas não só isso, considerando que o mito é fala e, portanto, não existem "conteúdos míticos", há nessa obra apenas uma forma, uma significação que se sobrepõe a um dado significado. N'O Conquistador, D. Sebastião é o objeto aquele de quem o sentido sobreposto, Sebastião, "fala", e que irá se instalando aos poucos no romance através de estratégias de aproximação e recusa que marcam as relações entre os dois heróis. Através disso se configura um movimento na obra em que um mito é desconstruído (o da História), enquanto outro (o da criação artística), "toma o seu lugar".

Márcia Gobbi reconhece que os mesmos epítetos que servem a $D$. Sebastião servem ao Sebastião da ficção, mas no sentido às avessas. O herói ficcional é o Encoberto, o Escolhido, o Desejado, porém das mulheres, e não do povo, como o outro. A ironia, a paródia e o mito, na perspectiva da autora, 
são identificados como os elos fundamentais do processo de deformação da História que o romance institui. A ficção se dá conta de que não pode ignorar ou rejeitar o passado literário das formas sacralizadas de expressão da História e de seus heróis sacralizados, mas pode abusar ironicamente desse passado valendo-se da construção paródica, mediada pela inversão irônica. Sebastião caminha em direção ao "mito", na esfera do mundo degradado; portanto o baixo dá a mão ao elevado - não sem antes dessacralizá-lo - o que não significa negá-lo. (GOBBI, 1997)

Através do enfoque na produção e nas características da escrita de Almeida Faria, Eliane de Alcântara Teixeira (2004) realiza também, em sua tese de doutoramento, uma revisão do mito sebástico. Olhando de modo especial para O Conquistador, romance que considera o mais completo no resgate do mito, ela procura apontar em que medida o autor propõe, em seu texto, a substituição dos ímpetos belicistas pelos ímpetos amorosos, via de regra, presentes no melhor da lírica da Literatura Portuguesa.

Assim, embora a fortuna crítica de Almeida Faria se estenda bem além do que apontamos nessa breve retomada, uma vez que restringimos bastante essa abordagem à crítica literária brasileira e, em especial, àquela que se debruça em torno da obra em análise, notamos bem quais têm sido os recortes, enfoques e as escolhas de temas dos críticos. A revisão ensejada pela obra em questão aponta para a exploração do mito realizada por Almeida Faria em seus textos de modo a se destacar a hábil utilização de alguns recursos argumentativos que tornam sua ficção tão rica para a análise literária. A fragmentação da linguagem, o uso da paródia, a inversão irônica e o caráter risível na criação ficcional são traços apontados por todas as críticas observadas. O presente trabalho não se constitui em oposição a isso, antes vem para se somar a esses trabalhos de investigação literária. Em nosso estudo, tecemos a nossa escritura não em busca de um dado novo, mas de um novo modo de interpretar os dados já percebidos e aceitos pela crítica consagrada.

\section{VIESES DA NARRATIVA DE O CONQUISTADOR}

Compreender como se estrutura a narrativa de O conquistador (1990) no nível do significante constitui passo inicial para que se proceda a sua leitura enquanto significado que dialoga com o mito. Para dar conta dessa tarefa, lançamos mão das considerações acerca do discurso da narrativa do teórico francês Gerárd Genette.

Abordando os problemas da narrativa, no sentido de contar uma história de ficção, Genette, em seu texto Discurso da Narrativa (1980), principia suas ponderações tomando como exemplo a clássica narrativa de Homero, a Odisséia. Diz ele que o discurso de Ulisses é uma ação, assim como o massacre dos pretendentes o é, mas se a existência das aventuras em nada depende dessa ação (massacrar os pretendentes), é evidente que o discurso narrativo (relato de Ulisses) depende delas absolutamente, pois é o seu produto (resultado das aventuras), como todo enunciado (discurso narrativo ou 
relato) é o produto de um ato de enunciação. Chegamos então à máxima de Aristóteles de que para a literatura não interessa a verdade, isto é, se as ações aconteceram ou não, importa antes a verossimilhança, a possibilidade de que tais ações pudessem ter acontecido e o resultado disso em forma de discurso narrativo. A partir daí, podemos começar a perceber as implicações dos três níveis de discurso que são abordados pelo teórico francês, segundo o que a análise do discurso narrativo significa o estudo das relações entre esse discurso (narrativa) e os acontecimentos que ele relata (história), e entre a narrativa e o ato que a produz (narração), conforme transcrevemos a seguir:

Proponho [...] denominar-se história o significado ou conteúdo narrativo, narrativa propriamente dita, o significante, enunciado, discurso ou texto narrativo em si, e narração o ato narrativo produtor e, por extensão, o conjunto da situação real ou fictícia na qual toma lugar. (GENETTE, 1995, p.25)

Com relação aos problemas da narrativa, Genette parte da divisão feita por Todorov em três categorias: primeiro a do tempo, onde se exprime a relação entre o tempo da história (aquilo que se conta) e o tempo do discurso (o texto propriamente); segundo a do aspecto, isto é, a maneira pela qual a história é percebida pelo narrador; e terceiro a do modo, ou seja, o tipo de discurso utilizado pelo narrador.

Genette divide as categorias de Todorov de outro modo ao reunir aspecto e modo em uma única grande categoria: a das modalidades de representação. O autor organiza os problemas da análise do discurso segundo categorias tomadas da gramática do verbo, apontando três classes fundamentais de determinações: as que estão ligadas às relações temporais entre narrativa e diegese (tempo); as que estão ligadas às modalidades de representação narrativa (modo); e aquelas que estão ligadas à maneira pela qual se encontra implicada, na narrativa, a própria narração, isto é, a situação ou instância narrativa (voz, relacionada com o sujeito ou instância da enunciação).

Considerando essas proposições de Genette, percebemos que em $O$ Conquistador a narrativa se organiza como autobiografia, ou seja, o relato de um passado vivenciado pelo narrador e protagonista das ações que se estende desde um tempo mais remoto (nascimento e momentos anteriores ao nascimento do herói) até o presente do narrador, a idade de vinte e quatro anos.

A fim de vermos o funcionamento disso no texto, cremos ser interessante retomar algumas passagens. Logo no primeiro capítulo do romance, ao falar de seu nascimento, o narrador traz o seguinte relato: "Acreditei durante muito tempo ter vindo ao mundo de um modo diferente de toda a gente. Foi minha avó Catarina - e as avós nunca mentem - quem me meteu essa ideia na cabeça" (FARIA, 1993, p. 11), ao que complementa parágrafos adiante: "Por mais que meus pais receassem irritar os ânimos difíceis de Catarina ao porem em causa o seu relato, não compreendo que o não fizessem mais tarde, caso fosse outra a verdade." (FARIA, 1993, p. 11). Referindo-se às circunstâncias 
que precederam o seu nascimento, o narrador relata que "Na véspera do [seu] nascimento caíra sobre a terra de Sintra a tempestade mais tremenda de que as pessoas se lembram" (FARIA, 1993, p. 12) e, ao refletir sobre essas memórias, faz a seguinte observação: "Muitas vezes, hoje mesmo, os sonhos me trazem imagens da catástrofe. Sinto arrepios ao evocar as circunstâncias que precederam e que de certo modo predisseram o instante em que vi a luz do dia". (FARIA, 1993, p. 13). Ao final desse capítulo inicial, o narrador nos situa em relação aos acontecimentos do momento a partir do qual ele narra: "Destes cumes contemplo os lugares da minha meninice [...]. Comecei a reconstruir uma antiga pousada de peregrinos, para nela atravessar a invernia. $\mathrm{O}$ trabalho manual fatiga-me [...]. De nada mais preciso neste dia do meu vigésimo quarto aniversário." (FARIA, 1993, p. 20).

Como verificamos, a partir dos fragmentos ilustrados, a narrativa, como relato dessa vivência, é o produto ou resultado das ações do protagonista. Por conseguinte, a narrativa é autodiegética - aquela em que o narrador é herói e não apenas testemunha das ações. O relato baseia-se inevitavelmente na memória, na capacidade de rememoração do protagonista dos episódios de sua vida. No entanto, o modo como se constrói esse texto expositivo implica idas e vindas que vão dos acontecimentos da vida do herói ao presente do narrador, momento a partir do qual ele narra, e vice-versa.

Assim, quanto à voz, a narrativa fariana é essencialmente ulterior, o narrador Sebastião de Castro concentra o seu relato nos fatos que já ocorreram, escreve sobre o tempo vivido. Entretanto, a exposição do narrador abarca toda sua existência, abordando inclusive considerações sobre o momento presente, o que exige também a presença da narrativa simultânea.

Com relação à perspectiva que orienta o relato, no sentido de pensar "quem é a personagem cujo ponto de vista orienta a perspectiva narrativa?" e "quem é o narrador?", ou "quem vê?" e "quem fala?", no caso de O Conquistador, ambos os papéis ficam com o narrador-protagonista Sebastião Correia de Castro. O narrador tem total domínio sobre o relato a ponto de as outras personagens só existirem no romance mediadas pela sua memória. Desse modo, não há diálogos ou falas em discurso direto no texto, mas apenas através do discurso indireto do narrador. Mesmo quando os acontecimentos ocorrem no presente, tudo nos chega através de seu relato, como, por exemplo, as suas conversas com os caseiros do sítio onde está hospedado, que estão entre as raras personagens com quem Sebastião mantem contato durante os sete meses de escritura de suas memórias:

Hoje mesmo os caseiros me segredaram que na próxima noite de sexta-feira, desde que a lua não se veja, surgirá por aí um touro enorme, com uma estrela branca entre os cornos. Se alguém o ferir nessa estrela, o rei Sebastião há-de aparecer, vindo do fundo do mar ou da llha Encoberta onde se esconde há quatro séculos. (FARIA, 1993, p. 129) 
O texto apresenta uma grande quantidade de informações sobre o protagonista, o que costuma caracterizar a narrativa mimética. Porém ele não "oculta" a presença de um narrador que organiza o relato, tornando-se assim mais diegético. Não há nenhuma intenção do protagonista de esconder-se por detrás do texto, mas de confessar-se, de se autoconhecer através da escritura, o que se evidencia nas seguintes falas:

Assaltado pelo supersticioso receio de não viver mais que $D$. Sebastião, e mergulhado na melancolia pela precariedade da vida, refugiei-me há um mês, durante o Natal do ano passado, na ermida da Peninha. [...] Só quero repensar, até o ameaçador mês de agosto, o que fiz e o que não fiz de mim. (FARIA, 1993, p. 19)

Assim que voltei a respirar os ares nativos, tratei de preparar a vinda para a Peninha, cujos caseiros conheço desde pequeno e me facilitaram por isso, sem contar a ninguém, esta estada aqui. Trouxe economias para sete meses. Inquieta-me o que me espera. Mas dúvida e desassossego são fiéis companheiros. (FARIA, 1993, p. 118)

A narrativa de O Conquistador, sendo uma autobiografia do herói, está impregnada de subjetividade na escolha dos fatos narrados, no modo como são narrados, na ênfase que é dada a um determinado episódio e não a outro. $O$ romance é marcado pela piada, pelo riso, pela leveza daquilo que conta - o que, no conjunto, intensifica a ironia que permeia o texto - no entanto poderia ser diferente, trata-se de uma escolha por esse modo de apresentação do texto.

\section{O RESGATE}

Dadas as linhas gerais do enredo ficcional, as possibilidades de leitura do título da obra - quem irá conquistador o quê? - nos sugere um universo polissêmico. O protagonista do romance, Sebastião Correia de Castro, aparentemente pouco tem em comum com o Rei Encoberto, D. Sebastião. O narrador inicia o relato a partir de algumas considerações sobre as circunstâncias de seu nascimento reladas a ele por sua avó materna, Catarina, a qual representa uma autoridade que referenda a história a ser contada. Como a narrativa se constitui da história pessoal de Sebastião, é o seu nascimento - como acontecimento inicial e singular - que gera, por consequência, todos os demais acontecimentos. Em seu percurso, da infância à vida adulta, acompanhamos as conquistas de Sebastião: conquista de seu espaço, do universo mágico, conquistas amorosas, conquista de si mesmo. Através de sete capítulos, o narrador-protagonista relata essas conquistas, constantemente aludindo à figura de $\mathrm{D}$. Sebastião.

O texto de Almeida Faria se inicia no vigésimo quarto aniversário do protagonista, quando ele, "[a]ssaltado pelo supersticioso receio de não viver mais que D. Sebastião, e mergulhado na melancolia, pela precariedade da 
vida, refu[giou-se] há um mês [...] na ermida da Peninha" para pensar sobre sua vida "até o ameaçador mês de agosto" (FARIA, 1993, p.19). Clandestino em Portugal, ocultando-se até mesmo de sua família, o narrador inicia a escritura de suas memórias.

Desde o início do texto, O conquistador refere o mito de D. Sebastião. O protagonista, homônimo do Desejado, nascendo no mesmo dia em que o Rei 20 de janeiro, dia de São Sebastião -, é desde cedo envolvido em uma lenda a respeito de sua vinda ao mundo. Após uma noite de tempestade nunca vista, em que ventos vindos do Norte da África fustigaram a costa alentejana - "O horizonte desapareceu completamente, uma escuridão de estanho esfumado avançara dos lados do Norte da África à velocidade de um tornado, atroando tudo com o barulho de todos os bombos e tambores do universo" (FARIA, 1993, p.13) - Sebastião teria aparecido na praia da Adraga, em meio a um espesso nevoeiro, dentro de um ovo. Seu pai, acompanhado de alguns cavaleiros, encontrara a criança e, sendo ela desejada por todos, João de Castro a ganhou matando a serpente que a guardava. Criança, Sebastião acreditara nessa história, narrada a ela pela avó e, adulto, interrogar-se-ia a respeito do porquê de seus pais nunca a terem posto em causa mais tarde, "caso fosse outra a verdade" (FARIA, 1993, p.12).

Além do nome e do dia do nascimento - em 1954, exatamente quatrocentos anos após a morte de D. Sebastião -, o protagonista tem em comum com o Rei o nome dos pais (João de Castro e Joana) e dos avós, Catarina e João. É interessante notar que o pai de D. Sebastião era o Infante D. João, mas viveu na mesma época um nobre de nome João de Castro que, no reinado de D. João III, ficou célebre como herói virtuoso e símbolo de honestidade. Pretendendo reedificar Diu, fortaleza na África, faltavam-Ihe os meios financeiros. Pediu-os então à Câmara de Goa, "sob forma de empréstimo, a pagar dentro de um ano. Em penhor [quis] mandar os ossos do filho; como não [fosse] possível, oferece[u] simbolicamente as suas barbas de homem de bem". (AMEAL, 1962, p.277). Catarina e João, seus avós, que na História corresponderiam a D. Catarina da Espanha e D. João III, pais do Infante D. João, na ficção passam a ser pais de Joana - historicamente, Joana da Áustria.

Catarina, personagem importante na vida de Sebastião de Castro, tendo acolhido-o por vários anos, mulher decidida, a quem ele chama de "mulherhomem" e "deusa tutelar" (FARIA, 1993, p.16-17), foi também o nome da avótutora de D. Sebastião, que foi abandonado pela mãe e cujo pai morrera vinte dias antes de seu nascimento.

Suas diferenças físicas em relação aos pais intrigam Sebastião desde cedo: "louro, entroncado, de olhos claros, curto o nariz, redonda a cara, a boca de carnudos lábios, o de baixo descaído como o de Catarina [...] com um feitio complicado, imaginação que perde o pé à realidade" (FARIA, 1993, p.16), mas o menino se assemelha, física e psicologicamente, a D. Sebastião, que tinha "os olhos amendoados, os cabelos alourados, a cara oval, o beiço belfo dos 
descendentes de Carlos $\mathrm{V}^{1}$, os dedos delicados, o tronco curto, desproporcionado em relação aos membros compridos demais" (FARIA, 1993, p.71). Semelhante ao rei, tem "atração pelo desconhecido e gosto pelo risco" e "[a]o contrário de [s]eu avô, a incerteza é forte [nele]" (FARIA, 1993, p.18). Durante a noite o protagonista é atormentado por "imagens de catástrofe", em sonhos com "homens que [o] queriam estrangular, trespassar à espada, à lança ou à facada" (FARIA, 1993, p.31), em lutas de duas gangs rivais. Narra:

Num dos bandos abunda gente de turbante, que pelo visto me considera seu inimigo, [...] sob o sol e a poeira que não me deixam ver e me fazem vacilar de tonturas e vômitos.

A carne queimada, o cheiro de pó e pólvora, o fumo escuro ardendo nos meus olhos, o pânico da dor, um tipo de cara repugnante, coberta de pústulas e úlceras que lhe dão o aspecto de um lobo com febre. A recorrência deste sonho tornou-se para mim mais inquietante ao encontrar, anos mais tarde, um marroquino que eu juraria ter conhecido. (FARIA, 1993, p.31-32)

Esses sonhos que, quase explicitamente, referem-se à fatídica batalha, ao mesmo tempo que ligam o protagonista ao Encoberto, são sintomáticos do menino cheio de imaginação, cuja história preferida era a de seu homônimo "a avó dava-[lhe] alento dizendo que um dia o Rei voltaria, numa certa madrugada, no meio da neblina" (FARIA, 1993, p.19) -, e que, ao procurar sua identidade, tornar-se-ia escritor.

Durante a infância de Sebastião, inúmeros acontecimentos vêm levantar maiores suspeitas em seus pais e nos demais habitantes de sua aldeia quanto à reencarnação, nele, do Encoberto. Vivendo em um ambiente extremamente supersticioso, a criança sexualmente precoce, que não fala até os três anos idade em que D. Sebastião tornou-se rei devido à morte de seu avô -, que brinca "de Corte", falando "línguas" ininteligíveis com duques, condes e princesas invisíveis, logo recebe o apelido de "Rei da Roca" (FARIA, 1993, p.34). Os acontecimentos de sua vida ganham sempre explicações baseadas no sobrenatural.

Como D. Sebastião, Sebastião não gosta de estudar, tem uma imaginação farta e gosta de "explorar" mundos distantes - ainda que neste caso seja através das obras de Júlio Verne. Como O Desejado, Sebastião de Castro tem saúde precária, sofrendo de vertigens e calafrios. Os sintomas doentios acometem o jovem geralmente durante sonhos. Porém, eles se intensificam quando, em visita ao Mosteiro dos Jerônimos em Lisboa, Sebastião se aproxima do suposto túmulo do rei. Nesse trecho da narrativa, transparece toda a dúvida e a incerteza que permeiam a obra e, de igual maneira, a vida do protagonista: "Os

\footnotetext{
1 Carlos $\mathrm{V}$ foi o pai de Joana de Áustria, mãe de D. Sebastião. Na ficção, os lábios de Sebastião se parecem com os de Catarina, sua avó materna.
} 
ossos, supostamente trazidas de África, não são decerto os seus. Só raramente a fama é verdadeira". (FARIA, 1993, p.73)

Essa visita ao túmulo e a reação do personagem têm um forte significado se comparadas ao comportamento de D. Sebastião que, recolhido em seus projetos, incompreendido em sua imaginação febril, sofria com uma grande solidão. Costumava visitar os túmulos dos reis de Portugal, ocasiões nas quais, segundo refere Joel Serrão (1971, p.315), parecia adquirir "estranhas energias" ao contato dos antepassados.

Desde cedo o medo de morrer constitui estigma do protagonista. Em muitas ocasiões ele expressa sua obsessão de que morreria no agosto de seus vinte e quatro anos, referência ao tempo em que D. Sebastião desapareceu na batalha, de tal maneira que atingir a fatídica idade vai implicar a necessidade de recolhimento de Sebastião. $O$ isolamento em que ele passa a viver - casulo de reflexões sobre a vida e o mundo - não deixa de ser uma espécie de morte.

No entanto, contrariamente ao seu homônimo, que tinha repulsa a mulheres, recusando-se a casar com Margarida de Valois e Isabel de Áustria, o "Rei da Roca" demonstra desde cedo uma grande aptidão para com o sexo oposto. Já na terceira série colegial, relaciona-se com a professora Justina que o "inicia" naquilo que seria seu fado: ser o "Cavaleiro do Amor", ainda que ele, como D. Sebastião, não desejasse casar-se, pois sua "religião [era] feita dos fluídos e eflúvios, calores e tremores do corpo da professora" (FARIA, 1993, p.47), em quem pensa quando está na missa. Sobre sua dedicação às mulheres, Sebastião considera: "achava preferível a companhia delas a ter que aturar as bazófias, balelas e verdades eternas dos representantes do meu sexo" (FARIA, 1993, p.127) e, a respeito da decisão de não se casar, ele afirma "Expliquei [à avó Catarina] então que as minhas pulsões não me permitiriam dedicar-me a uma mulher apenas, e nunca em regime exclusivo." (FARIA, 1993, p.17).

Ao contrário do Outro, Sebastião de Castro, não é adepto a aspirações guerreiras, foge ao serviço militar e afirma que "A [sua] missão, se a tinha, não se compadecia com guerras sem sentido." (FARIA, 1993, p.111). Sobre o fato de o herói grego Ulisses ter abandonado o leito de Calipso, interroga-se: "seria crível que um herói, conceituado após uma década de passatempos bélicos, se fartasse dos menos trabalhosos feitos eróticos? Nunca gramei guerreiros. Desde então detestei-os." (FARIA, 1993, p.65).

Opondo-se ao "apostolado laico" do protagonista, temos um D. Sebastião extremamente dedicado à religião católica, que não se aceitou casar por ser misógeno e que, desde criança, desejou ser "O Cavaleiro de Cristo". (AMEAL, 1962)

No final de sete meses de isolamento - período em que Sebastião é visitado apenas por um amigo, única pessoa externa ao sítio que sabe de seu esconderijo - e de sete capítulos de memórias transpostas para a escrita, os últimos dias no sítio da Peninha chegam cobertos de brumas, embora a rádio 
tenha anunciado céu limpo. Nesse instante de isolamento e de criação artística, o protagonista encontra-se "entorpecido", enrolado em si mesmo.

Sebastião de Castro, embora interprete a fala dos caseiros sobre a vinda próxima de um touro que, se atingido, revelará o Rei Encoberto, como "história para afugentar assombrações e domesticar as noites temíveis" (FARIA, 1993, p.129), recebe, à noite, a visita da figura de D. Sebastião. Relata:

\begin{abstract}
Seja sonho meu ou desenho do meu amigo que todas os meses me traz novos esboços, ultimamente aparece-me de noite uma figura nua que podia ser meu duplo e que vem em silêncio, calçando luvas compridas e usando na cabeça a mitra dos dignatários e príncipes. Pára diante de mim e apóia numa rocha a grossa espada, de punho escamoso terminada em boca de drago. Está rodeado por quatro monstruosos animais, como os símbolos dos Evangelistas cercam o Filho do Homem nalguns ícones, e representam o sal do desejo, o pez da nostalgia, o mercúrio do movimento, o enxofre da melancolia. Como se fosse um sol, sete estrelas giram à minha volta. São as sete Plêiades, da constelação do Touro [data do desaparecimento de D. Sebastião], e de repente tranqüiliza-me a evidência de que aquele Sete-Estrelo me há de guiar pela vida fora e me há de defender de morrer cedo. (FARIA, 1993, p.130)
\end{abstract}

Reatualizando ironicamente o mito histórico, existente ainda no século XX, D. Sebastião agora é uma "metáfora da nação portuguesa". Através de seu Conquistador, o autor realiza o resgate do passado - a imagem de D. Sebastião ainda permanece viva e visita o protagonista - mas, ao mesmo tempo, a subversão da história do herói mítico, como pretendemos demonstrar a seguir.

\title{
A SUBVERSÃO
}

Almeida Faria nos revela um suposto D. Sebastião às avessas daquele representado pela historiografia tradicional. Um Sebastião (História) tem órgão sexual infantil e aversão ao sexo oposto; o outro (ficção) é bem dotado e faz sucesso com as mulheres. Um Sebastião ama a guerra e morre em combate; o outro acha a guerra sem sentido. Um Sebastião vem para salvar a nação portuguesa, enquanto o outro foge do país para não cumprir com suas obrigações militares. Todas essas são oposições explicitas no romance, são formas de subversão da historiografia tradicional. Todas essas inversões paródicas polemizam a ficção fariana.

Retomando o caminho do mito, para dimensionar o sebastianismo, o consideramos como fenômeno fundador da nacionalidade de um povo, sentido que ultrapassa o religioso ou o antropológico e alcança a ideia de ideologia. Além da relação estrutural, é no plano da linguagem e da ideologia que se completa o embate com o mito em O Conquistador. Assim, o nível dos enunciados soma-se ao plano da enunciação. Os enunciados evidenciam a recomposição do mito, enquanto a enunciação aponta sempre para o seu deslocamento. 
Roland Barthes (1977) nos oferece uma noção da abordagem de mito enquanto ideologia. Repensando suas formulações sobre mito contemporâneo, Barthes propõe algumas reformulações de seus primeiros conceitos a fim de contemplar o trabalho de análise da linguagem que tal tratativa comporta.

Barthes destaca que a ideia inicial de mito, segundo o pensamento contemporâneo, estaria de acordo com algumas articulações teóricas iniciais. Uma primeira é a de que que o mito - próximo ao que a sociologia durkheimiana denomina "representação coletiva" - se faz presente nos enunciados da imprensa, da publicidade, do objeto de grande consumo, constituindo um determinado social, um "reflexo". A segunda é a de que, de acordo com a imagem de Marx, trata-se de um reflexo invertido, ou seja, o mito consiste em transpor a cultura em natureza. Estruturas sociais, ideológicas e históricas, decorrentes da própria atividade humana, são transplantadas em "natural". Tudo isso é apresentado como "evidente por si mesmo". Em terceiro lugar vem a ideia de que o mito é marcado pela descontinuidade, ele não mais se enuncia em grandes narrativas, mas em "discurso", constituindo uma espécie de fraseologia (conjunto de frases). O mito desaparece, mas, enquanto discurso, permanece tanto mais insidioso, transformando-se naquilo que é mítico. Por fim, como palavra (mythos), o mito na contemporaneidade diz respeito a uma semiologia (ciência dos signos) que permite retificar a inversão mítica, descompondo a mensagem em dois sistemas semânticos: um sistema conotado, cujo sentido é ideológico; e um sistema denotado, cuja função é naturalizar a proposição de classe, dando-lhe a garantia da mais "inocente" das naturezas: a da linguagem. (BARTHES, 1977)

Dando um passo além dessas proposições iniciais, Barthes percebe que se a sociedade não mudou desde as suas primeiras formulações sobre mito, a ciência da leitura mudou e tomou o mito como um outro objeto. Nesse sentido, ele intensifica a visão do mito em sua dimensão de fenômeno linguístico: a partir da revolução teórica que se processou com o pós-estruturalismo, a ciência do significante toma os trabalhos da vez, a qual pretende menos a análise do signo do que a sua deslocação. Não se pode mais separar facilmente o significante do significado, o ideológico do fraseológico, porque essa distinção também se tornou, de algum modo, mítica. A denúncia, a desmitificação, tornou-se ela própria discurso. Diante disso é necessário que a ciência do significante se detenha mais longe na sua averiguação, não mais na dissociação do signo (significante/significado), mas na sua própria vacilação. (BARTHES, 1977)

Para Barthes (1977), não são mais os mitos que é preciso desmascarar, é o próprio signo que tem que ser abalado. É necessário mais do que revelar o sentido latente de um enunciado, de um traço, de uma narrativa, mas "fissurar" a própria representação do sentido. Mais do que "purificar" ou "mudar" os símbolos, é preciso contestar o símbolo em si. A semiologia começou por 
estabelecer um léxico mitológico, mas hoje a sua tarefa é antes de ordem sintática do que de revelação semântica.

Barthes nota que cada vez mais cabe à semiologia a tarefa de esmiuçar a linguagem no sentido de perceber "de quais articulações, de quais deslocamentos linguísticos é composto o tecido mítico de uma sociedade de alto consumo" (BARTHES, 1977, p.13). Primeiro visou-se a destruição do sentido - da ideologia escamoteada nos gestos culturais. Agora, diante da percepção de que tudo é linguagem, objetiva-se a destruição do signo.

O teórico francês acredita que se a alienação da sociedade requer que se desmitifique a linguagem (especialmente a dos mitos), o meio adequado para isso não é mais o deciframento crítico, mas a avaliação. As linguagens são mais ou menos espessas. Algumas, as mais sociais, as mais míticas, apresentam uma homogeneidade inabalável. Tecida de hábitos, de repetições, de esteriótipos, de cláusulas obrigatórias e de palavras-chave, cada uma constitui um idioleto, ou mais exatamente, um socioleto. Mais, portanto, do que mitos, são atualmente socioletos, ou seja, linguagem de grupos sociais, que se faz necessário distinguir e descrever. Às mitologias, sucederia uma idioletologia, cujos conceitos operatórios não seriam mais o signo, o significante, o significado e a conotação, mas a citação, a referência, o esteriótipo. (BARTHES, 1977).

As características de mito como fenômeno linguístico, acreditamos, estão presentes na abordagem que Almeida Faria faz do sebastianismo no seu romance de 1990. Em parte isso aparece na esteriotipização do apego do povo português aos mitos nacionais, processo muitas vezes alienatório, o que se evidencia no romance através da força de "verdade" que o mito sebástico adquire na pequena comunidade onde nasce e cresce o protagonista, algo que não se verifica entre outras pessoas com quem, mais tarde, ele irá conviver, como Helena e Clara, por exemplo, pessoas esclarecidas e que vivem em grandes cidades. O narrador explicita isso ao comentar o que Ihes segredaram os caseiros do sítio sobre o possível ressurgimento do rei D. Sebastião. Nas palavras dele, "Não admira que, em tão ásperos sítios, as pessoas procurem amenizar o invisível, preenchendo-o de histórias para afugentar assombrações e domesticar as noites temíveis." (FARIA, 1993, p. 129) Porém, é especialmente no que se refere a essa inovação no estudo da linguagem, a esse debruçar-se sobre o discurso, que a narrativa de $O$ Conquistador admite o alargamento de algumas reflexões sobre o ato de escrever, de criar um texto, seja ele denominado historiográfico ou ficcional.

O romance coloca em confronto vários idioletos, o do povo da aldeia, o das "sociedades secretas" (como a Société pour l'Usage Convencionable des Hommes (SUCH) e o grupo dos sebastianistas de Sintra), o da conquista amorosa, o da astrologia e numerologia (conhecimentos de Helena) e o dos estudiosos da História (como Clara). Tudo atravessado pelo olhar algo divertido e irônico do narrador. 
No romance fariano, o narrador trilha o caminho mais contundente de subversão do mito, a averiguação linguística. O modo provocativo, gozador e desprovido de seriedade com que o mito é referido nO conquistador cria uma imagem que sugere a desmistificação daquela história que se sustentou durante séculos em Portugal. Mais do que isso, o que se quer agora é repensar o mito mesmo como tema cultural. Cremos que para o romance de Almeida Faria se encaixe a formulação de Raul Fiker de que

A simples manifestação das formas próprias do mito num contexto que não mais as comporta, já configura um desencaixe, um equívoco, uma trapalhada. Seu desacordo com o contexto e seu estatuto aberrante comportam possibilidades cômico-burlescas que estão a propósito do anacronismo histórico como dispositivo paródico. (FIKER, 1983, p.18)

Melhor dizendo, o Sebastianismo, devido ao próprio deslocamento no tempo histórico, ganha um olhar que percebe o seu desencaixe e, por consequência, encaminha sua leitura para a esfera do cômico, mediado quase sempre pela inversão paródica.

Os recursos de referencialidade, citação, ironia e paródia utilizados em 0 Conquistador operam uma função estrutural na narrativa. Através de um Sebastião de Castro mulherengo, em oposição escandalosa ao casto D. Sebastião, Almeida Faria consegue elaborar uma interessante mecânica de identificações e de contrastes - texto parodiado/texto receptor, atingindo uma paralelização, em termos de igualdade, entre obra literária e sensibilidade histórica.

No encalço dessa averiguação dos recursos ficcionais que tecem o texto d'O Conquistador, acreditamos que algumas formulações da obra de Mikhail Bakhtin sobre a cultura popular na Idade Média, resultantes do estudo realizado pelo autor a respeito do contexto de François Rabelais, permitem esclarecer alguns processos de construção textual realizados na obra. Embora não creiamos que haja propriamente a carnavalização (principal formulação teórica de Bakhtin nesse estudo) dentro do romance - lembremos que o uso generalizado de profanações e blasfémias, juras, imprecações, obscenidades e expressões de teor insultuoso definem a linguagem carnavalesca, o que não se aplica ipsis litteris ao romance em estudo -, cremos que alguns traços da ironia e da paródia se assemelham ao que Bakhtin levanta na obra rabelaisiana.

Conforme alguns teóricos da modernidade que estudam a paródia, uma de suas marcas é o caráter ambivalente, ou seja, ao tempo que pretende a degradação do alvo evocado, a paródia opera o seu fortalecimento justamente pela força da evocação. Também Bakhtin ressalta a ambivalência como uma das características marcantes da cultura popular da Idade Média, o que, de certa forma, aproxima os cultos cômicos antigos da paródia da modernidade. Diz Bakhtin que "as grosserias blasfematórias dirigidas às divindades constituíam um elemento necessário dos cultos cômicos mais antigos. Essas blasfêmias eram ambivalentes: embora degradassem e mortificassem, 
simultaneamente regeneravam e renovavam" (BAKHTIN, 1999, p.15). No contexto geral da obra $O$ Conquistador, observamos um esquema semelhante quando aceitamos que um processo de inversão embasa o enredo. Ao retomar a história e a trajetória pessoal de D. Sebastião em termos paródicos e, portanto, de inversão - reiteremos que para o D. Sebastião conquistador de territórios está o Sebastião conquistador de mulheres -, o texto questiona e rebaixa a história oficial. Ainda que, inevitavelmente, reafirme sua importância ao recorrer a esta como fonte para a sua criação ficcional.

Além disso, outro elemento nos chama a atenção nesse processo de rebaixamento efetuado no romance fariano. Na trajetória de Sebastião de Castro sempre o corpo e a existência carnal se sobrepõem à vida espiritual. $O$ jovem dedica sua existência a atividades libidinosas. Admiravelmente precoce, o protagonista desperta para a sexualidade ainda bebê, e quando chega à idade adulta, também momento de escritura de suas memórias, parece já ter alcançado o ápice da vida libertina depois de ter servido como amante "profissional" à SUCH no período em que viveu em Paris.

Ainda menino, quando era "arrastado" pela mãe à igreja da Ulgueira para assistir missas, Sebastião pensava na professora Justina, seu amor do terceiro ano colegial. Na redação de suas memórias, o narrador diz que "lembrava Justina quando o padre entoava 'tomai e comei, este é o meu corpo, tomai e bebei, este é o meu sangue'. [A sua] religião era feita dos fluídos e eflúvios, calores e tremores do corpo da professora." (FARIA, 1993, p. 47). A partir disso, entendemos o lugar que ocupou desde sempre na existência de Sebastião a religião e a igreja. Parece que ambas eram relegadas a segundo plano, não lhes sendo dedicada a solenidade que costumeiramente exigem. Novamente realiza-se um processo de inversão no que se refere à figura de $D$. Sebastião: para o jovem rei, a religião estava em primeiro lugar e a sua crença era fervorosa.

Mikhail Bakhtin ressalta o processo de elevação que tem na obra de Rabelais o "princípio da vida material e corporal". A essa marca da obra rabelaisiana, Bakhtin chama realismo grotesco. Nas palavras do autor: "O traço marcante do realismo grotesco é o rebaixamento, isto é, a transferência ao plano material e corporal, o da terra e do corpo na sua indissolúvel unidade, de tudo que é elevado, espiritual, ideal e abstrato". (BAKHTIN, 1999, p.17, grifo do autor)

Bakhtin ressalta que essa ênfase no princípio da vida material e corporal não se refere apenas ao sexo, mas à satisfação de todas as necessidades naturais. N'O conquistador, destaca-se, de modo semelhante, além do prazer sexual, o prazer de comer, quando o narrador fala da volúpia com que Helena comia (FARIA, 1993, p.107), ou mesmo de defecar, quando lembra o prazer que sentia quando ainda criança sentava na latrina e se aquecia, em dias frios de inverno, no calor das próprias fezes (FARIA, 1993, p.28). Seja acasalar, comer ou defecar, são todos processos fisiológicos e diretamente ligados ao baixo corporal que estão em primeiro plano na trajetória de Sebastião. 
O riso, como característica fundamental do decurso paródico ou irônico, torna-se peça essencial desse rebaixamento ao qual viemos nos referindo. Bakhtin esclarece que a partir do século XVII o riso passa a ser encarado de forma diferente ao da antiguidade. A partir de então,

o riso não pode ser uma forma universal de concepção do mundo, ele pode referir-se apenas a certos fenômenos parciais e parcialmente típicos da vida social, a fenômenos de caráter negativo; o que é essencial e importante não pode ser cômico; a história e os homens que a encarnam (reis, chefes de exército, heróis) não podem ser cômicos; o domínio do cômico é restrito e específico (vícios dos indivíduos e da sociedade); não se pode exprimir na linguagem do riso a verdade primordial sobre o mundo e o homem, apenas o tom sério é adequado. (BAKHTIN, 1999, p.57-58)

Portanto, há uma profunda seriedade em tomar a história do maior herói do povo lusitano, o qual se tornou um dos grandes mitos nacionais, em termos risíveis. Bakhtin ainda salienta que uma característica que marca fundamentalmente o riso popular é a sua ligação (relação) essencial com a verdade popular não-oficial:

O riso da Idade Média, que venceu o medo do mistério, do mundo e do poder, temerariamente desvendou a verdade sobre o mundo e o poder. Ele opôs-se à mentira, à adulação e à hipocrisia. A verdade do riso degradou o poder, fez-se acompanhar de injúrias e blasfêmias e o bufão foi o seu portavoz. (BAKHTIN, 1999, p.80)

Nesse sentido é que acreditamos que se constrói o "jogo dos Sebastiãos", a imagem do heróico refletida no medíocre desconstrói uma verdade oficial por meio do humor. Sebastião de Castro explora a semelhança com o rei para impressionar as mulheres, mas ele afirma que não quer ser guerreiro, que sua missão "não se compadecia com guerras sem sentido" (FARIA, 1993, p. 111). A questão que fica exposta é a seguinte: foi o jovem $D$. Sebastião um grande guerreiro ou um inconsequente que, compadecendo-se com guerras sem sentido, levou muitos inocentes à morte, além de perder a própria vida? Caso aceitemos a segunda hipótese, então não poderia tal "herói" redimir e salvar a nação portuguesa.

Na medida em que aponta para a desmitificação, o romance de Almeida Faria aposta na segunda alternativa. Não é por outro motivo que sua ficção "brinca" com a hipótese de uma reencarnação em cujo centro das ações aparecem as conquistas amorosas, algo que em tudo nega o heroísmo trágico formulado pela figura original na longa jornada mítica que experimentou na cultura portuguesa. 


\title{
CONSIDERAÇÕES FINAIS
}

O conquistador é um romance, antes de tudo, divertido, embora remeta a questões bastante sérias para a cultura portuguesa. O texto, por muitos aspectos, apresenta-se em consonância com uma linha de ficção contemporânea que parte de questões históricas remotas ou recentes para repensá-las ou revisá-las. Almeida Faria opera esse processo crítico através da utilização de recursos desestabilizadores como a intertextualidade, a paráfrase, a ironia, a inversão paródica e a metalinguagem.

O autor constrói o protagonista através de uma mecânica de identificações e de contrastes com D. Sebastião, herói mítico da cultura lusitana. A relação estabelecida é, na verdade, muito mais de contrastes ou de inversões do que de aproximação. A personagem da ficção, constituída em oposição à personagem histórica, causa riso. O riso, por sua vez, característica constante na obra, torna-se uma grande arma de ridicularização. Nesse sentido, a leitura de Mikhail Bakhtin nos auxiliou na interpretação do riso enquanto recurso de rebaixamento.

No entanto, embora aparente descaso em relação aos problemas do contexto atual, o enredo ficcional, através do próprio silêncio, configura-se como uma forma de protesto. O narrador relata que fugiu de Portugal para escapar da convocação à guerra nas colônias africanas por considerá-la sem sentido. Atitude bem questionável a alguém que poderia ser a reencarnação do "guerreiro" D. Sebastião.

A propósito, o conhecimento dos fatores históricos que permitiram a instauração do sebastianismo em Portugal esclarece o alcance das críticas operadas pelo processo utilizado por Almeida Faria. Relendo a História, encontramos em Sebastião I uma biografia de derrotas e de negações bastante singular e interessante, sobretudo, se pensarmos na esperança messiânica que lhe foi desde sempre depositada. Surge daí, justamente, a força de "antiherói" que encontramos no Sebastião da ficção.

\section{THE RESCUE AND THE SUBVERSION OF THE HISTORICAL MYTH IN O CONQUISTADOR, BY ALMEIDA FARIA}

\begin{abstract}
This article is the result of a Master's dissertation defended in the year 2006. In the present text, it was analyzed the studied book, by considering two aspects: the recovery and subversion of historical myth from Portuguese culture, as the author retakes the trajectory of Dom Sebastian and the Sebastianism myth birth to build this character and, at the same time, he subverts this when he suggests the king's reincarnation upside down. As examples of theoretical concepts
\end{abstract}


which support this reading, it is studied the idea of myth as ideology, proposed by Roland Barthes, with some formulation about irony and parody, in which Mikhail Bakhtin approaches the rabelaisian work, that is applied to the context of this research. Faria's text presents a character in permanent identity crisis, who bears the stigma of being physically identical to the famous king, but has a personality quite different from his.

Keywords: Portuguese Literature. Sebastianism Myth. History.

\section{REFERÊNCIAS}

AMEAL, João (1962). História de Portugal. 5. ed. Porto: Tavares Martins.

BAKHTIN, Mikhail (1999). A cultura popular na Idade Média e no

Renascimento: o contexto de François Rabelais; tradução de Yara Frateschi Vieira. 5. ed. São Paulo: Hucitec.

BARTHES, Roland (1977). Mudar o próprio objeto. In: LUCCIONI, Gennie et al. Atualidade do mito; tradução de Carlos Arthur R. do Nascimento. São Paulo: Duas Cidades.

FARIA, José de Almeida (1993). O Conquistador. Rio de Janeiro: Rocco.

FIKER, Raul (1983). Mito e paródia: sua estrutura e seu funcionamento no texto literário. Tese de Mestrado IEL/Unicamp. Campinas.

GENETTE, Gerárd (1995). Discurso da narrativa; tradução de Fernanda Cabral Martins. 3. ed. Alpiarça, Santarém: Vegas.

GOBBI, Márcia Valéria (1997). De Fato, Ficção (um exame da ironia como mediadora das relações entre Historia e Literatura em romances de José Saramago e Almeida Faria). Tese (Doutorado em Estudos Comparados de Literatura Portuguesa) - Universidade de São Paulo. São Paulo.

SERRÃO, Joel (Org.) (1971). Dicionário de História de Portugal. Porto: Figueirinhas.

SIMÕES, Maria de Lourdes Netto (1998). As razões do imaginário: comunicar em tempos de revolução - 1960-1990 - a ficção de Almeida Faria. Salvador: FCJA (UESC).

(1975). Narrativa Portuguesa: em processo de fragmentação. Rio de Janeiro: Petrópolis.

TEIXEIRA, Eliane de Alcântara (2004). Almeida Faria e a Revisão do Mito Sebástico. Tese (Doutorado em Literatura Portuguesa) - Universidade de São Paulo. São Paulo. 